
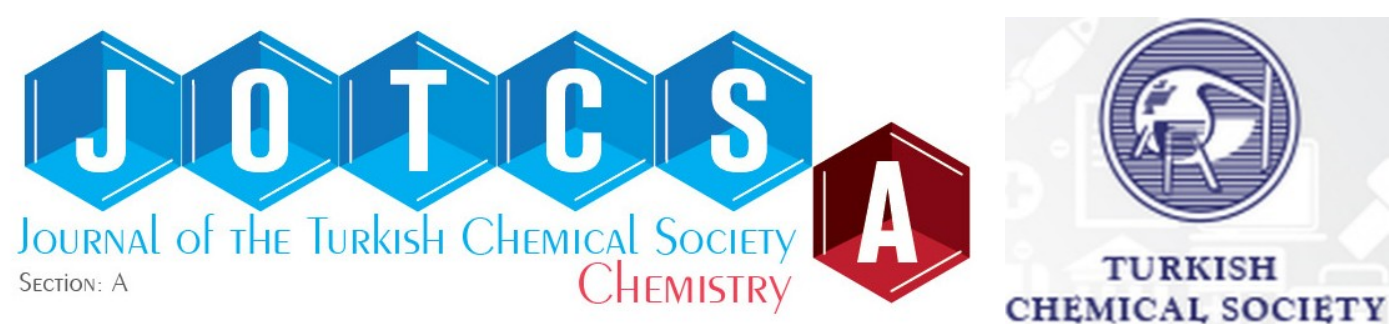

\title{
Regioselective Synthesis of Some Rhamnopyranoside Esters for PASS Predication, and ADMET Studies
}

\author{
Mohammed Mahbubul Matin ${ }^{1 *} \triangle D$, Naimul Islam ${ }^{1} \triangle D$, Aysha Siddika ${ }^{1}$ iD, and \\ Sreebash C. Bhattacharjee ${ }^{1,2}$ iD
}

${ }^{1}$ University of Chittagong, Faculty of Science, Department of Chemistry, 4331, Chattogram, Bangladesh.

${ }^{2}$ Bangladesh Council of Scientific \& Industrial Research (BCSIR), Chemical Research Division, 4220, Chattogram, Bangladesh.

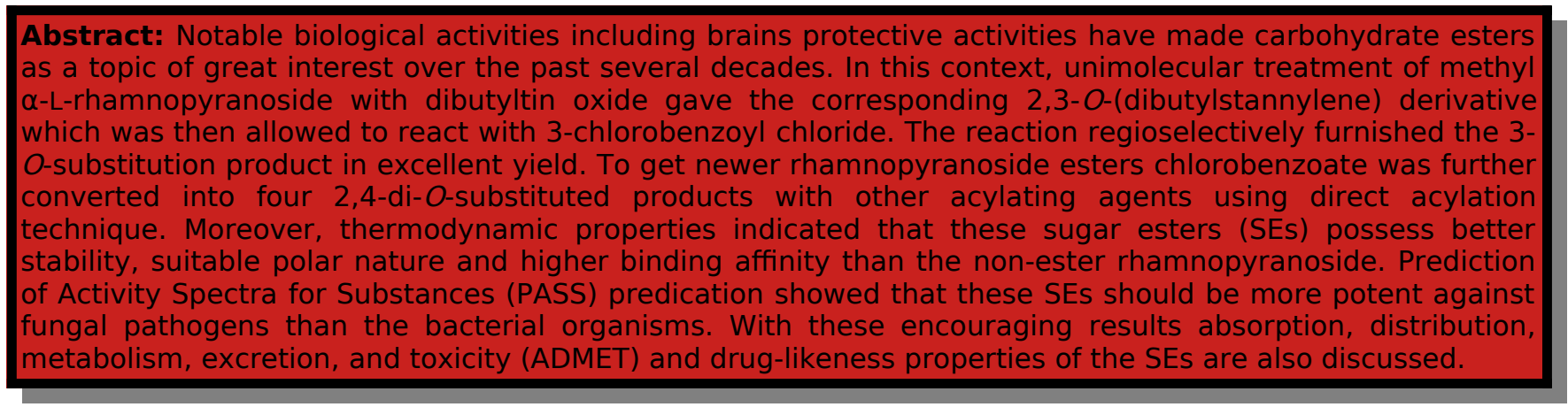

Keywords: Dibutyltin oxide (DBTO) method, Methyl $\alpha$-L-rhamnopyranoside, Regioselectivity, PASS predication, AdmetSAR.

Submitted: November 23, 2020. Accepted: January 18, 2021.

Cite this: Matin MM, Islam N, Siddika A, Bhattacharjee SC. Regioselective Synthesis of Some Rhamnopyranoside Esters for PASS Predication, and ADMET Studies. JOTCSA. 2021;8(1):363-74.

DOI: https://doi.org/10.18596/jotcsa.829658.

*Corresponding author. E-mail: mahbubchem@cu.ac.bd, Tel: +880-1716-839689, Fax: +880-31-2606014.

\section{INTRODUCTION}

Sugar esters (SE) are composed of a sugar moiety and one or more acyl group(s) (1). Due to the presence of both hydrophilic and lipophilic moieties, SEs are biodegradable, environmentally friendly, non-toxic, non-allergic, and non-irritating (2-3). Their good stabilizing properties render them to use in the food, cosmetics, pharmaceutical formulations, and bioremediation of pollutants (4-6). In addition to their surfactant properties, SEs possess anticancer, insecticidal and antimicrobial activities (7-9). Some SEs are used as intermediate for the synthesis of many natural and synthetic biomolecules including glycosylation (10). Hence, SEs are getting more attention as a vivid field of research to the organosynthetic and biological chemists (11).
Among SEs, rhamnopyranoside based esters got special interest as they are active in many natural products (12-13) and showed cytotoxic activity against several different cell lines. For instance, brasilicardin A (1, Figure 1) was isolated from the broth of actinomycete Norcardia brasiliensis IFM0406 which contains two rhamnopyranosyl moieties. Addition of 3-hydroxybenzoate esters in the 3- and 4-positions of its rhamnose unit(s) is responsible for immunosuppressive activities (14). $S$. buergeriana derived 2-O-acetyl-3,4-di-O-(E)- $p$ methoxycinnamoyl- $\alpha$-L-rhamnopyranoside exerted significant protective effects against glutamateinduced neurodegeneration (15). In 2020, Elmaidomy et al. (16) isolated four novel rhamnopyranose esters (2a-d, Figure 1) from the 
stem of $P$. odorata which exhibited triple-negative breast cancer suppressive activities along with antioxidant properties. We reported in our previous studies that the incorporation of ester group(s) at different position of rhamnose enhanced its antimicrobial functionality (17-18) like other SEs (19). Some of the SEs were found promising against SARS-CoV-2 main protease than the hydroxychloroquine (HCQ) (20).

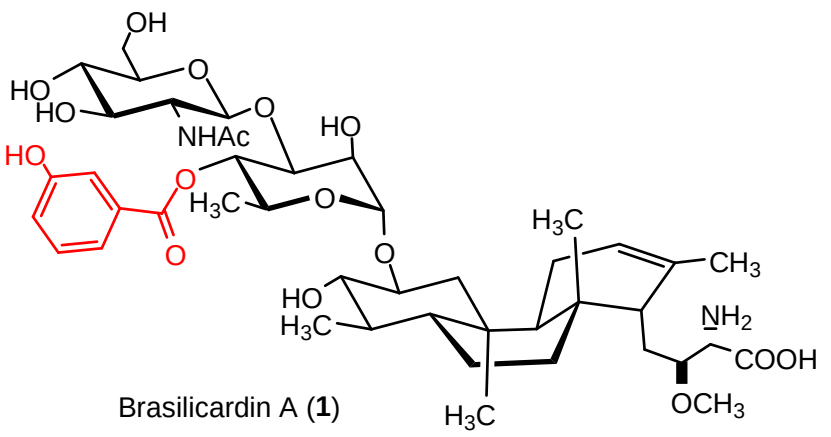

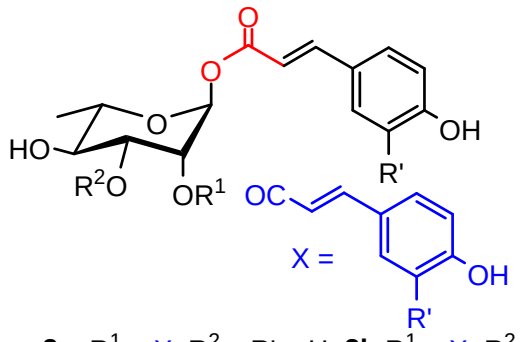

2a: $R^{1}=X, R^{2}=R^{\prime}=H ; 2 b R^{1}=X, R^{2}=$ $H, R^{\prime}=O H ; 2 c: R^{1}=H, R^{2}=X, R^{\prime}=H$; 2d: $R^{1}=H, R^{2}=X, R^{\prime}=O H$

Figure 1. Naturally occurring rhamnopyranose esters.

The chemical synthesis of carbohydrate esters by hydroxyl group protection/deprotection strategies is essential for the synthesis of oligosaccharides and carbohydrate-conjugates. This needs regio- and stereochemical control to get desired SEs. However selective and regioselective esterification (acylation) of monosaccharide molecules is a difficult task due to the presence of multiple $2^{\circ}$ hydroxyl groups of similar reactivity (21). Hence, development of selective esterification methods for sugar modification is highly desired. Several methods (2223) with different reaction conditions (21) were developed where dibutyltin oxide (DBTO) method was found to be promising (24). In this paper, the regioselective synthesis of 3-O-(3chlorobenzoyl)rhamnopyranosides from methyl $\alpha-L-$ rhamnopyranoside (3) employing DBTO method is described with DFT based thermodynamic properties, PASS predication, and drug-likeness (ADMET) studies.

\section{EXPERIMENTAL}

\section{Materials and general methods}

Methyl $\alpha$-L-rhamnopyranoside (3) and related reagents/solvents were commercially available (Merck, Germany), and were used as received, unless otherwise specified. TLC (thin layer chromatography) was conducted on plates coated with Kieselgel $\mathrm{GF}_{254}$, and the spots were detected by spraying the plates with $1 \% \mathrm{H}_{2} \mathrm{SO}_{4}$ and heating at 150-200 ${ }^{\circ} \mathrm{C}$ until blackish coloration took place. CC (column chromatography) was conducted with silica gel $\mathrm{G}_{60}$. In both the cases solvent system employed was $n$-hexane/ethyl acetate (EA) in different ratios. Reduced pressure using a bath temperature below $40{ }^{\circ} \mathrm{C}$ was maintained for evaporations. FT-IR spectra were recorded on a FT-IR spectrophotometer (Shimadzu, IR Prestige-21) in $\mathrm{CHCl}_{3}$ technique. ${ }^{1} \mathrm{H}$ NMR $(400 \mathrm{MHz})$ spectra were recorded for solutions in $\mathrm{CDCl}_{3}$ using tetramethylsilane (TMS) as an internal standard with a Bruker DPX-400 spectrometer at the
Bangladesh Council of Scientific and Industrial Research (BCSIR) Laboratories, Dhaka, Bangladesh.

\section{Synthesis of methyl 3-O-(3-chlorobenzoyl)- $\alpha$-L-} rhamnopyranoside (4)

A suspension of methyl $\alpha$-L-rhamnopyranoside (3) (200 mg, $1.122 \mathrm{mmol}$ ) and dibutyltin oxide (307 mg, 1.1 molar eq) in anhydrous methanol (10 mL) was heated under gentle reflux in nitrogen atmosphere until a clear solution was obtained $(\sim 4 \mathrm{~h})$. After refluxing for an additional hour, the solvent was removed, and the resulting intermediate tin complex (3a) was obtained as a white solid. A stirred suspension of the tin complex (3a) in dry dioxane $(10 \mathrm{~mL})$ was treated with 3-chlorobenzoyl chloride $(0.15 \mathrm{~mL}, 1.1$ molar eq) and stirring was continued at room temperature overnight. Removal of solvent and silica gel column chromatography (with $n$ hexane-EA, 1:4 as eluent) furnished the title compound 4 (317 mg, 89\%) as needles, mp 140-142 ${ }^{\circ} \mathrm{C}$ (ethyl acetate- $n$-hexane) (25). $R_{\mathrm{f}}=0.46$ (with $n$ hexane/EA $=1 / 2)$; FT-IR $\left(\mathrm{CHCl}_{3}\right) \nu_{\max }\left(\mathrm{cm}^{-1}\right)$ : 3360$3560(\mathrm{OH}), 1695(\mathrm{CO}) ;{ }^{1} \mathrm{H}$ NMR $\left(400 \mathrm{MHz} \mathrm{CDCl}_{3}\right) \delta_{\mathrm{H}}$ ppm: $8.15(\mathrm{~s}, 1 \mathrm{H}, \mathrm{Ar}-H), 8.05(\mathrm{~d}, J=7.9 \mathrm{~Hz}, 1 \mathrm{H}, \mathrm{Ar}-$ $H), 7.65(\mathrm{~d}, J=8.0 \mathrm{~Hz}, 1 \mathrm{H}, \operatorname{Ar}-H), 7.50-7.54(\mathrm{~m}, 1 \mathrm{H}$, Ar- $H$ ) , $5.15(\mathrm{dd}, J=9.4$ and $3.3 \mathrm{~Hz}, 1 \mathrm{H}, \mathrm{H}-3), 4.65(\mathrm{~d}$, $J=1.5 \mathrm{~Hz}, 1 \mathrm{H}, \mathrm{H}-1) 3.72-3.76(\mathrm{~m}, 3 \mathrm{H}, \mathrm{H}-2, \mathrm{H}-4$ and $\mathrm{H}-5), 3.40\left(\mathrm{~s}, 3 \mathrm{H}, \mathrm{OCH}_{3}\right), 1.33(\mathrm{~d}, 3 \mathrm{H}, J=5.7 \mathrm{~Hz}$, $\mathrm{CH}_{3}$ ).

\section{Synthesis of methyl 3-O-(3-chlorobenzoyl)-2,4- di-O-methanesulfonyl- $\alpha$-L-rhamnopyranoside (5)}

To a solution of the $4(50 \mathrm{mg}, 0.158 \mathrm{mmol})$ in dry pyridine $(1 \mathrm{~mL})$ was added methanesulfonyl chloride (40 mg, $0.349 \mathrm{mmol}$ ) slowly at $0{ }^{\circ} \mathrm{C}$ followed by addition of a catalytic amount of DMAP (4- N,Ndimethylaminopyridine). The reaction mixture was allowed to attain room temperature and stirring was continued for $5 \mathrm{~h}$. A small amount of ice-water $(0.2$ $\mathrm{mL})$ was added to the reaction mixture to decompose excess mesyl chloride, and extracted 
with DCM (dichloromethane, $3 \times 3 \mathrm{~mL}$ ). The combined DCM extract was washed successively with 5\% hydrochloric acid, saturated aqueous sodium hydrogen carbonate solution and brine. The DCM layer was dried over $\mathrm{Na}_{2} \mathrm{SO}_{4}$, and concentrated under reduced pressure. The residue was then purified by CC (elution with $n$-hexane/EA, 12:1) and furnished the 2,4-di-O-mesyl esters 5 (68 mg, 91\%) as a pale yellow oil. $R_{\mathrm{f}}=0.49(n$-hexane/EA $=5 / 1)$; FT-IR $\left(\mathrm{CHCl}_{3}\right) v_{\max }\left(\mathrm{cm}^{-1}\right): 1703$ (CO), 1370, 1365 $\left(\mathrm{SO}_{2}\right) ;{ }^{1} \mathrm{H}$ NMR $\left(400 \mathrm{MHz}, \mathrm{CDCl}_{3}\right) \delta_{\mathrm{H}} \mathrm{ppm}: 7.91(\mathrm{~s}, 1 \mathrm{H}$, Ar- $H$ ), $7.76(\mathrm{~d}, J=7.8 \mathrm{~Hz}, 1 \mathrm{H}, \operatorname{Ar}-H), 7.47(\mathrm{~d}, J=8.0$ $\mathrm{Hz}, 1 \mathrm{H}, \operatorname{Ar}-H), 7.33-7.37(\mathrm{~m}, 1 \mathrm{H}, \operatorname{Ar}-H), 5.46(\mathrm{dd}, J=$ 9.3 and $3.3 \mathrm{~Hz}, 1 \mathrm{H}, \mathrm{H}-3), 5.35(\mathrm{~d}, J=3.3 \mathrm{~Hz}, 1 \mathrm{H}, \mathrm{H}$ 2), $5.25(\mathrm{t}, J=9.4 \mathrm{~Hz}, 1 \mathrm{H}, \mathrm{H}-4), 4.70(\mathrm{~s}, 1 \mathrm{H}, \mathrm{H}-1)$, 3.90-3.95 (m, 1H, H-5), $3.42\left(\mathrm{~s}, 3 \mathrm{H}, \mathrm{OCH}_{3}\right), 3.31(\mathrm{~s}$, $\left.3 \mathrm{H}, \mathrm{SO}_{2} \mathrm{CH}_{3}\right), 3.15\left(\mathrm{~s}, 3 \mathrm{H}, \mathrm{SO}_{2} \mathrm{CH}_{3}\right), 1.28(\mathrm{~d}, J=6.0$ $\mathrm{Hz}, 3 \mathrm{H}, \mathrm{CH}_{3}$ ).

\section{Synthesis of methyl 3-O-(3-chlorobenzoyl)-2,4- di-O-pivaloyl- $\alpha$-L-rhamnopyranoside (6)}

To a rapidly stirred and cooled $\left(0^{\circ} \mathrm{C}\right)$ solution of the diol 4 (50 $\mathrm{mg}, 0.158 \mathrm{mmol}$ ) in anhydrous pyridine (2 $\mathrm{mL}$ ) was slowly added pivaloyl chloride (42 mg, $0.348 \mathrm{mmol}$ ), and stirring was continued at this temperature for $10 \mathrm{~h}$. Conventional work-up procedure as described earlier followed by CC purification ( $n$-hexane-EA, 10:1) provided the di- $O$ pivaloate 6 (72 $\mathrm{mg}, 94 \%)$ as clear needles, mp 85$87^{\circ} \mathrm{C} . R_{\mathrm{f}}=0.53(n$-hexane/EA $=5 / 1) ;$ FT-IR $\left(\mathrm{CHCl}_{3}\right)$ $\nu_{\max }\left(\mathrm{cm}^{-1}\right): 1738,1732,1701$ (CO); ${ }^{1} \mathrm{H}$ NMR (400 $\left.\mathrm{MHz}, \mathrm{CDCl}_{3}\right) \delta_{\mathrm{H}}$ ppm: $7.96(\mathrm{~s}, 1 \mathrm{H}, \mathrm{Ar}-H), 7.79(\mathrm{~d}, J=$ $7.8 \mathrm{~Hz}, 1 \mathrm{H}, \mathrm{Ar}-H), 7.46(\mathrm{~d}, J=8.1 \mathrm{~Hz}, 1 \mathrm{H}, \mathrm{Ar}-H)$, 7.34-7.38 (m, $1 \mathrm{H}, \mathrm{Ar}-H), 5.43(\mathrm{dd}, J=9.6$ and $3.4 \mathrm{~Hz}$, $1 \mathrm{H}, \mathrm{H}-3), 5.36(\mathrm{~d}, J=3.4 \mathrm{~Hz}, 1 \mathrm{H}, \mathrm{H}-2), 5.27(\mathrm{t}, J=$ $9.6 \mathrm{~Hz}, 1 \mathrm{H}, \mathrm{H}-4), 4.68(\mathrm{~s}, 1 \mathrm{H}, \mathrm{H}-1), 3.88-3.91(\mathrm{~m}, 1 \mathrm{H}$, $\mathrm{H}-5), 3.42\left(\mathrm{~s}, 3 \mathrm{H}, \mathrm{OCH}_{3}\right), 1.27(\mathrm{~d}, J=5.9 \mathrm{~Hz}, 3 \mathrm{H}$, $\left.\mathrm{CH}_{3}\right), 1.20\left(\mathrm{~s}, 9 \mathrm{H}, \mathrm{C}\left(\mathrm{CH}_{3}\right)_{3}\right), 1.18\left(\mathrm{~s}, 9 \mathrm{H}, \mathrm{C}\left(\mathrm{CH}_{3}\right)_{3}\right)$.

\section{Synthesis of methyl 3-O-(3-chlorobenzoyl)-2,4- di-O-pentanoyl- $\alpha$-L-rhamnopyranoside (7)}

A stirred and cooled solution of the diol 4 (50 $\mathrm{mg}$, $0.158 \mathrm{mmol})$ in dry pyridine $(2 \mathrm{~mL})$ was treated with pentanoyl chloride (42 $\mathrm{mg}, 0.348 \mathrm{mmol}$ ) and stirring was continued at this temperature for $12 \mathrm{~h}$. The reaction was stopped by adding ice-water. Usual work-up followed by column chromatography furnished the di-O-pentanoate 7 (66 mg, 86\%) as a clear syrup which resisted crystallization. $R_{\mathrm{f}}=0.52$ $(n$-hexane/EA $=5 / 1)$; FT-IR $\left(\mathrm{CHCl}_{3}\right) v_{\max }\left(\mathrm{cm}^{-1}\right)$ : 1748, 1742, 1698 (CO); ${ }^{1} \mathrm{H}$ NMR $\left(400 \mathrm{MHz}, \mathrm{CDCl}_{3}\right) \delta_{\mathrm{H}} \mathrm{ppm}$ : 7.93 (s, 1H, Ar-H), 7.80 (d, J= $7.6 \mathrm{~Hz}, 1 \mathrm{H}, \operatorname{Ar}-H), 7.45$ $(\mathrm{d}, J=8.0 \mathrm{~Hz}, 1 \mathrm{H}, \operatorname{Ar}-H), 7.33-7.37(\mathrm{~m}, 1 \mathrm{H}, \operatorname{Ar}-H)$, $5.42(\mathrm{dd}, J=9.5$ and $3.2 \mathrm{~Hz}, 1 \mathrm{H}, \mathrm{H}-3), 5.34(\mathrm{~d}, J=$ $3.2 \mathrm{~Hz}, 1 \mathrm{H}, \mathrm{H}-2), 5.27(\mathrm{t}, J=9.5 \mathrm{~Hz}, 1 \mathrm{H}, \mathrm{H}-4), 4.65$ $(\mathrm{s}, 1 \mathrm{H}, \mathrm{H}-1), 3.89-3.94(\mathrm{~m}, 1 \mathrm{H}, \mathrm{H}-5), 3.41(\mathrm{~s}, 3 \mathrm{H}$, $\left.\mathrm{OCH}_{3}\right), 2.27-2.36\left(\mathrm{~m}, 4 \mathrm{H}, 2 \times \mathrm{CH}_{3}\left(\mathrm{CH}_{2}\right)_{2} \mathrm{CH}_{2} \mathrm{CO}\right), 1.53$ $1.64\left(\mathrm{~m}, 4 \mathrm{H}, 2 \times \mathrm{CH}_{3} \mathrm{CH}_{2} \mathrm{CH}_{2} \mathrm{CH}_{2} \mathrm{CO}\right), 1.28(\mathrm{~d}, J=6.0$ $\left.\mathrm{Hz}, 3 \mathrm{H}, \mathrm{CH}_{3}\right)$, 1.19-1.31 (m, 4H, $\left.2 \times \mathrm{CH}_{3} \mathrm{CH}_{2}\left(\mathrm{CH}_{2}\right)_{2} \mathrm{CO}\right)$, 0.84-0.94 (m, $\left.6 \mathrm{H}, 2 \times \mathrm{CH}_{3}\left(\mathrm{CH}_{2}\right)_{3} \mathrm{CO}\right)$.

Synthesis of methyl 3-O-(3-chlorobenzoyl)-2,4di-O-hexanoyl- $\alpha$-L-rhamnopyranoside (8)
Hexanoyl chloride (47 mg, $0.349 \mathrm{mmol}$ ) was slowly added to an ice-cooled suspension of diol 4 (50 mg, $0.158 \mathrm{mmol})$ in pyridine $(2 \mathrm{~mL})$. The reaction mixture was allowed to attain the room temperature and stirred for additional $12 \mathrm{~h}$ when TLC indicated the formation of a faster-moving single product. The reaction was stopped by adding ice-water $(0.2 \mathrm{~mL})$ and extracted with DCM $(3 \times 3 \mathrm{~mL})$. The combined DCM extract was treated successively with $5 \%$ hydrochloric acid, saturated aqueous sodium hydrogen carbonate solution, and brine. The organic layer was dried over $\mathrm{Na}_{2} \mathrm{SO}_{4}$, and concentrated under diminished pressure. The residue was then subjected to CC (elution with $n$-hexane/EA, 12:1), and gave the 2,4-di-O-hexanoate 8 ( $71 \mathrm{mg}, 88 \%)$ as a thick liquid. $R_{\mathrm{f}}=0.55(n$-hexane/EA $=5 / 1) ; \mathrm{FT}-\mathrm{IR}$ $\left(\mathrm{CHCl}_{3}\right) \nu_{\max }\left(\mathrm{cm}^{-1}\right):$ 1754, 1745, 1698 (CO); ${ }^{1} \mathrm{H}$ NMR $\left(400 \mathrm{MHz}_{1} \mathrm{CDCl}_{3}\right) \delta_{\mathrm{H}} \mathrm{ppm}: 7.94(\mathrm{~s}, 1 \mathrm{H}, \mathrm{Ar}-H), 7.83$ (d, $J=7.8 \mathrm{~Hz}, 1 \mathrm{H}, \operatorname{Ar}-H), 7.44(\mathrm{~d}, J=8.0 \mathrm{~Hz}, 1 \mathrm{H}, \operatorname{Ar}-H)$, $7.37(\mathrm{t}, J=4.6 \mathrm{~Hz}, 1 \mathrm{H}, \mathrm{Ar}-H), 5.40(\mathrm{dd}, J=9.8$ and $3.3 \mathrm{~Hz}, 1 \mathrm{H}, \mathrm{H}-3), 5.33(\mathrm{~d}, J=3.3 \mathrm{~Hz}, 1 \mathrm{H}, \mathrm{H}-2), 5.28$ $(\mathrm{t}, J=9.8 \mathrm{~Hz}, 1 \mathrm{H}, \mathrm{H}-4), 4.64(\mathrm{~s}, 1 \mathrm{H}, \mathrm{H}-1), 3.85-3.904$ $(\mathrm{m}, 1 \mathrm{H}, \mathrm{H}-5), 3.42\left(\mathrm{~s}, 3 \mathrm{H}, \mathrm{OCH}_{3}\right), 2.25-2.35(\mathrm{~m}, 4 \mathrm{H}$, $\left.2 \times \mathrm{CH}_{3}\left(\mathrm{CH}_{2}\right)_{3} \mathrm{CH}_{2} \mathrm{CO}\right)$, 1.54-1.64 (4H, $\mathrm{m}$, $\left.2 \times \mathrm{CH}_{3}\left(\mathrm{CH}_{2}\right)_{2} \mathrm{CH}_{2} \mathrm{CH}_{2} \mathrm{CO}\right), 1.26(\mathrm{~d}, J=6.2 \mathrm{~Hz}, 3 \mathrm{H}$, $\left.\mathrm{CH}_{3}\right)$, 1.18-1.32 (m, 8H, $\left.2 \times \mathrm{CH}_{3}\left(\mathrm{CH}_{2}\right)_{2}\left(\mathrm{CH}_{2}\right)_{2} \mathrm{CO}\right), 0.88-$ $0.94\left(\mathrm{~m}, 6 \mathrm{H}, 2 \times \mathrm{CH}_{3}\left(\mathrm{CH}_{2}\right)_{4} \mathrm{CO}\right)$.

\section{Thermodynamic properties calculation}

For thermodynamic properties calculation quantum mechanical based density functional theory (DFT) was used. Initial geometry of the rhamnopyranoside 3 was taken from the Chemspider website. Necessary modification for other compounds 4-8 was conducted using the the GaussView (5.0) program (26). All the compounds were then optimized by Lee, Yang, and Parr's (LYP) correlation functional under 3-21G basis set with Gaussian 09 program (26). The optimized structures were used to calculate their thermodynamic properties.

\section{PASS Predication}

For the prediction of activity spectra for substances (PASS) the freely accessible web resource PASS Online (http://www.way2drug.com/passonline/) was used (27). This in silico generated results are suitable for understanding pharmacological profile of drug related compounds. Initially, the structures of 3-8 were drawn with ChemDraw 16.0, and then converted into their SD file format, and applied to predict the biological spectrum like antibacterial, antifungal, anticarcinogenic and antioxidant properties using this software. Generally, predicted results are expressed as $\mathrm{Pa}$ (probability for active substance) and $\mathrm{Pi}$ (probability for inactive substance). With the increasing value of $\mathrm{Pa}$ and decreasing value of $\mathrm{Pi}$, the chance of experimentally finding of a given activity increases. That is $\mathrm{Pa}$ should be greater than $\mathrm{Pi}$ and the considered scale is 0.000 to 1.000 .

ADMET calculation

Absorption, distribution, metabolism, excretion, and 
toxicity (ADMET) prediction could avoid the huge cost and time associated with the in vivo experiments during drug discovery. In the present investigation, in silico ADMET was calculated using pkCSM program (http://biosig.unimelb.edu.au) (28). Appropriate stereochemical structures of the SEs 3 8 were converted to the corresponding SMILES (simplified molecular-input line-entry system) and SD file formats, and used for the calculation of pkCSM-pharmacokinetics. The similar SMILES and SD file formats were also used to predict druglikeness properties using SwissADME free web tools (http://www.swissadme.ch) (29). Overall druglikeness score was also predicted (http://www.molsoft.com/mprop/mprop.cgi) (30).

\section{RESULTS AND DISCUSSION}

\section{Regioselective 3-chlorobenzoylation of methyl} $\alpha$-L-rhamnopyranoside (3)

Initially, methyl $\alpha$-L-rhamnopyranoside (3) was transformed into the intermediate tin complex $\mathbf{3} \mathbf{a}$ by treatment with the dibutyltin oxide in anhydrous methanol under reflux condition. The formation of the tin complex 3a may be explained by considering the mechanism proposed by Tsuda et al. (31), which states that in cases of glycoses or glycosides where there is a cis-vicinal glycol system present, formation of a highly stable five-membered stannylene ring is more favorable between an axialequatorial pair. Tin complex $\mathbf{3 a}$, on unimolecular reaction with 3-chlorobenzoyl chloride, furnished a solid (mp 140-142 ${ }^{\circ} \mathrm{C}$ ) in good yield (Scheme 1 ). The appearance of absorption bands at 3360-3560 and $1695 \mathrm{~cm}^{-1}$ in its FT-IR spectrum suggested the presence of carbonyl and hydroxyl groups in the molecule i.e. partial chlorobenzoylation of the molecule. In the ${ }^{1} \mathrm{H}$ NMR spectrum, appearance of four aromatic protons at $\delta 8.15(\mathrm{~s}, 1 \mathrm{H}), 8.05(\mathrm{~d}, 1 \mathrm{H})$, $7.65(\mathrm{~d}, 1 \mathrm{H})$ and $7.50-7.54(\mathrm{~m}, 1 \mathrm{H})$ clearly indicated the addition of one chlorobenzoyl group in the molecule. A doublet at $\delta 4.65$ with small coupling constant $(1.5 \mathrm{~Hz})$ was assigned for equatorially oriented $\mathrm{H}-1$. We noticed huge downfield shift of $\mathrm{H}-3$ to $\delta 5.15$ from its usual value ( $\delta 4.00 \mathrm{ppm}$ ) (32) which suggested the incorporation of 3chlorobenzoyl group at $\mathrm{C}-3$ position. Thus, the compound was assigned as methyl 3-O-(3chlorobenzoyl)- $\alpha$-L-rhamnopyranoside (4).

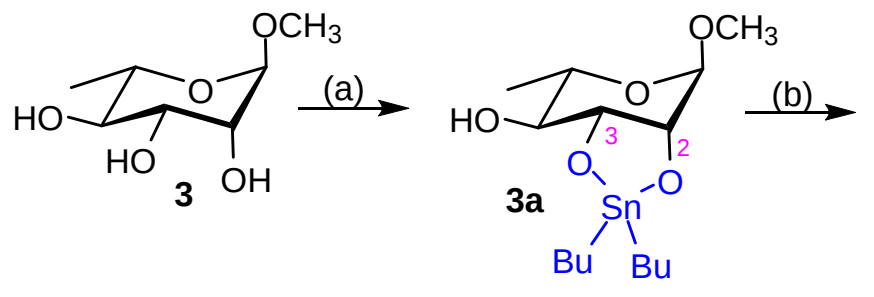<smiles>COC1OC2OC1C(O)C(OC(=O)c1cccc(Cl)c1)C(O)C2C</smiles>

Scheme 1. Regioselective chlorobenzoylation of rhamnopyranoside 3. Reaction conditions: (a) $\mathrm{Bu}_{2} \mathrm{SnO}_{\text {, }}$ $\mathrm{MeOH}$, reflux, 4 h; (b) 3-Cl. $\mathrm{C}_{6} \mathrm{H}_{4} \mathrm{COCl}$, 1,4-dioxane, rt, 12 h, $89 \%$.

The regioselective 3-O-(3-chlorobenzoylation) of rhamnopyranoside $\mathbf{3}$ may be rationalized by assuming that a highly stable five-membered stannylene ring $\mathbf{3} \mathbf{a}$ was formed between the cisvicinal glycol system $(2-\mathrm{OH}$ and $3-\mathrm{OH})$ of the rhamnoside 3 (Scheme 1). The formation of the tin complex 3a was in conformity with the mechanism proposed by Tsuda et al. (31). The equatorial hydroxyl group at position C-3 of $\mathbf{3 a}$ was activated most during acylation (31), thereby, forming solely the 3-O-substitution product with the unimolar 3chlorobenzoyl chloride. The structure of the 3-O-(3- chlorobenzoyl) derivative $\mathbf{4}$ was also further confirmed by the preparation and characterization of its four 2,4-di-O-acyl derivatives 5-8.

\section{Synthesis of 2,4-di-O-acyl esters 5-8 of chlorobenzoylrhamnopyranoside 4}

To get newer rhamnopyranoside esters as well as to confirm the structural information of chlorobenzoate 4, four 2,4-di-O-acyl esters 5-8 were synthesized and characterized. Initially, treatment of diol $\mathbf{4}$ with dimolar mesyl chloride at low temperature furnished a pale yellow oil (Scheme 2 ).
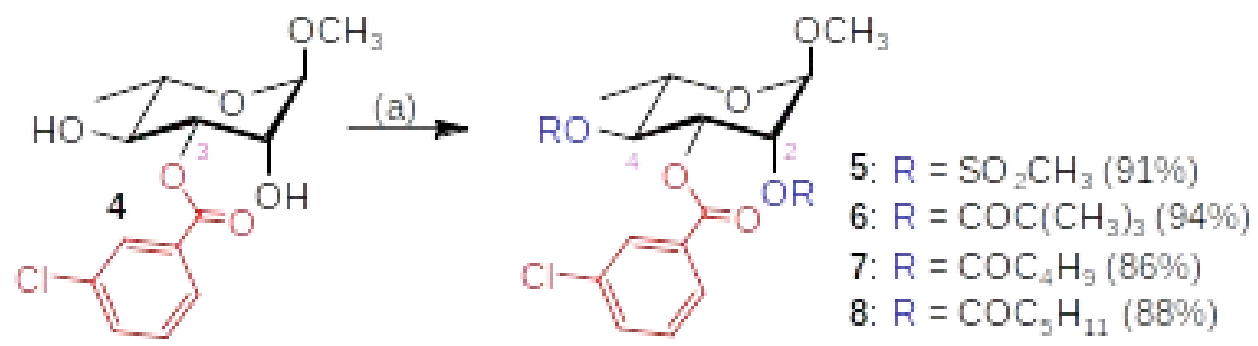

Scheme 2. 2,4-Di-O-acylation of chlorobenzoate 4. Reaction conditions: (a) $\mathrm{CH}_{3} \mathrm{SO}_{2} \mathrm{Cl} /\left(\mathrm{CH}_{3}\right)_{3} \mathrm{CCOCl} / \mathrm{C}_{4} \mathrm{H}_{9} \mathrm{COCl} /$ $\mathrm{C}_{5} \mathrm{H}_{11} \mathrm{COCl}$, dry $\mathrm{Py}, 0{ }^{\circ} \mathrm{C}-\mathrm{rt}, 5-12 \mathrm{~h}$. 
Appearance of two new bands at 1370 and 1365 $\mathrm{cm}^{-1}$ in addition to carbonyl stretching $\left(1703 \mathrm{~cm}^{-1}\right)$, and disappearance of hydroxyl band in the FT-IR spectrum clearly indicated the complete mesylation of the molecule. This fact was further confirmed by its ${ }^{1} \mathrm{H}$ NMR spectrum where two new three-proton singlets were found at $\delta 3.31$ and $3.15 \mathrm{ppm}$ corresponding to two mesyl groups. The C- 6 methyl protons appeared at $\delta 1.28$, and $\mathrm{C}-1 \mathrm{OCH}_{3}$ appeared at $\delta$ 3.42. However, considerable downfield shift of $\mathrm{H}-2$ ( $\delta$ 5.35) and $\mathrm{H}-3$ ( $\delta 5.25)$ as compared to its precursor chlorobenzoate 4 ( $\delta$ 3.72-3.76 as multiplet) confirmed the attachment of mesyl groups at C-2 and C-4 positions. On the basis of spectroscopic evidences, the structure of the molecule was established as methyl 3-O-(3chlorobenzoyl)-2,4-di-O-methanesulfonyl- $\alpha$-L-rhamnopyranoside (5).

In the subsequent step, reaction of the diol $\mathbf{4}$ with pivaloyl chloride for $10 \mathrm{~h}$ followed by chromatography furnished clear needles (mp 85-87 ${ }^{\circ} \mathrm{C}$ ) in excellent yield (Scheme 2). Disappearance of hydroxyl bands and presence of three carbonyl stretching bands at 1738, 1732 and $1701 \mathrm{~cm}^{-1}$ in its FT-IR spectrum clearly indicated the complete pivaloylation of the compound. ${ }^{1} \mathrm{H} \quad \mathrm{NMR}$ also supported the above fact where two nine-proton singlets appeared at $\delta 1.20$ and 1.18 corresponding to two pivaloyl groups. In addition, $\mathrm{H}-2$ ( $\delta 5.36)$ and $\mathrm{H}-4$ ( $\delta$ 5.27) appeared downfield than the diol 4 ( $\delta$ 3.72-3.76) affirming the attachment of pivaloyl groups at C-2 and C-4 positions. So, the structure of the compound was established as methyl 3-O-(3chlorobenzoyl)-2,4-di-O-pivaloyl- $\alpha$-L-rhamnopyranoside (6).

Reaction of diol $\mathbf{4}$ with excess pentanoyl chloride in dry pyridine followed by chromatograpy furnished a faster-moving syrup in $86 \%$ (Scheme 2). Its FT-IR spectrum showed the absence of hydroxyl stretching, and the presence of carbonyl bands at 1748, 1742 and $1698 \mathrm{~cm}^{-1}$ indicating the attachment of pentanoyl groups in the molecule. The fact was confirmed by analyzing its ${ }^{1} \mathrm{H}$ NMR spectrum where extra eighteen protons appeared at $\delta$ 2.27-2.36 (m, $4 \mathrm{H}), 1.53-1.64(\mathrm{~m}, 4 \mathrm{H}), 1.19-1.31(\mathrm{~m}, 4 \mathrm{H})$ and $0.84-$ $0.94(\mathrm{~m}, 6 \mathrm{H})$. Also, $\mathrm{H}-2$ and $\mathrm{H}-4$ shifted considerable downfield as compared to its precursor 4. Hence, the compound was assigned as methyl 3-O-(3chlorobenzoyl)-2,4-di-O-pentanoyl- $\alpha$-L-rhamnopyranoside (7).

Finally, dimolar hexanoylation of the 2,4-diol 4 with hexanoyl chloride followed by chromatography gave a thick liquid in good yield (Scheme 2). Its FT-IR spectrum exhibited characteristic carbonyl bands at 1754, 1745 and $1698 \mathrm{~cm}^{-1}$, and band related to hydroxyl group was disappeared. In the ${ }^{1} \mathrm{H}$ NMR spectrum additional twenty-two protons appeared in the aliphatic region which confirmed the attachment of two hexanoyl groups in the molecule. Downfield shift of $\mathrm{H}-2$ ( $\delta 5.33)$ and $\mathrm{H}-4$ ( $\delta 5.28)$ as compared to the diol 4 indicated the attachment of hexanoyloxy groups at C-2 and C-4 positions. Thus, the compound was established as methyl 3-O-(3chlorobenzoyl)-2,4-di-O-hexanoyl- $\alpha$-L-rhamnopyranoside (8).

\section{Thermodynamic \\ rhamnopyranosides}

properties

of

Having successful preparation of rhamnose based SEs 4-8 we have calculated their thermodynamic properties based on quantum mechanical DFT optimization (26). The optimized structures (298.15 $\mathrm{K}, 1.0 \mathrm{~atm})$ of 3-8 are shown in Figure 2.
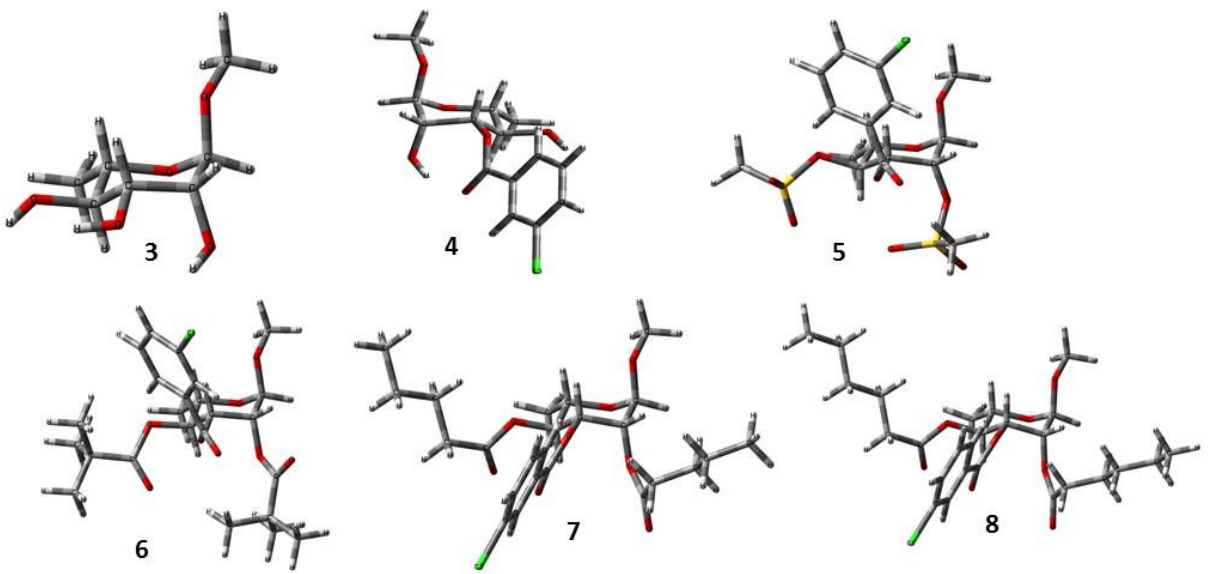

Figure 2. DFT optimized (B3LYP/3-21G) conformational structures of 3-8.
It was found that these SEs possess ${ }^{1} C_{4}$ conformation with similar $\mathrm{Cl}$ symmetry (Figure 2) which are in consistance with their ${ }^{1} \mathrm{H}$ NMR spectral data. Thermodynamic properties such as electronic energy $(E E)$, enthalpy $(\Delta H)$, Gibbs' free energy $(G)$ and dipole moment $(\mu)$ of the optimized rhamnopyranosides 3-8 are summarized in Table 1. With the increase of the negative energy value, the electrons become more tightly bound with the nucleus. It is worth mentioning that addition of ester group(s) increased electron binding tendency (-1447 to -2631 Hartree) than the parent 
rhamnopyranoside 3 (-651.2403 Hartree). The highest electron binding was observed for dimesylate 5 (-2631.008 Hartree) indicating the more stability of the compound. This fact was further supported by the lower $\Delta \mathrm{H}$ values (more negative values) of SEs than the non-ester sugar $\mathbf{3}$ (Table 1). Gibbs free energy (G) of the SEs (1447.2685 to -2630.6936 Hartree) was found very much lower than the non-ester 3 (-651.0598
Hartree) which indicated their spontaneous binding, and interaction with other substrates. In addition, dipole moment $(\mu)$ of a molecule signifies the measure of net molecular polarity and binding affinity. It was observed that the addition of ester group(s) gradually increased $\mu$ as compared to nonester rhamnopyranoside $\mathbf{3}$. This suggested the more polar nature and higher binding affinity with target enzyme of the SEs 4-8 $(3,23)$.

Table 1: Thermodynamic properties of the synthesized rhamnopyranoside based SES.

\begin{tabular}{cllllll}
\hline Molecule & MF & MW & $\boldsymbol{E E}$ (Hartree) & $\boldsymbol{\Delta H}$ (Hartree) & $\boldsymbol{G}$ (Hartree) & $\boldsymbol{\mu}$ (Debye) \\
\hline $\mathbf{3}$ & $\mathrm{C}_{7} \mathrm{H}_{14} \mathrm{O}_{5}$ & 178.18 & -651.2403 & -651.0075 & -651.0598 & 2.6783 \\
$\mathbf{4}$ & $\mathrm{C}_{14} \mathrm{H}_{17} \mathrm{ClO}_{6}$ & 316.73 & -1447.5915 & -1447.2685 & -1447.3395 & 3.8598 \\
$\mathbf{5}$ & $\mathrm{C}_{16} \mathrm{H}_{21} \mathrm{ClO}_{10} \mathrm{~S}_{2}$ & 472.90 & -2631.0080 & -2630.5985 & -2630.6936 & 8.1775 \\
$\mathbf{6}$ & $\mathrm{C}_{24} \mathrm{H}_{33} \mathrm{ClO}_{8}$ & 484.19 & -1985.8611 & -1985.2751 & -1985.3785 & 7.2095 \\
$\mathbf{7}$ & $\mathrm{C}_{24} \mathrm{H}_{33} \mathrm{ClO}_{8}$ & 484.19 & -1985.8379 & -1985.2501 & -1985.3593 & 8.4353 \\
$\mathbf{8}$ & $\mathrm{C}_{26} \mathrm{H}_{37} \mathrm{ClO}_{8}$ & 513.02 & -2064.0407 & -2063.3925 & -2063.5082 & 8.5241
\end{tabular}

\section{PASS Predicted biological activities}

The basic aim of the biological activity spectrum was to describe the properties of biologically active substances. In this respect online-based Prediction of Activity Spectrum for Substances (PASS) software (http://www.way2drug.com/passonline/) is efficiently used to find novel targets for biological activities (33). PASS results, as shown in Table 2, indicated that the synthesized SEs 4-8 possess better antifungal activity $(0.70>\mathrm{Pa}>0.42) \quad$ than antibacterial

property

(0.54>Pa>0.47). Incorporation of ester group(s) increased antifungal potentiality of rhamnopyranoside molecule $\mathbf{3}$ except methanesulfonyl ester 5. Antifungal potentiality of pentanoyl (7) and hexanoyl (6) esters were comparable to the standard antibiotic tetracycline and fluconazole. However, incorporation of ester moieties did not increase anti-carcinogenic and antioxidant properties (Table 2).

Table 2: PASS predicted biological activities of rhamnopyranoside 3-8.

\begin{tabular}{cllllllll}
\hline \multirow{2}{*}{ Drug } & \multicolumn{2}{l}{ Antibacterial } & \multicolumn{3}{l}{ Antifungal } & \multicolumn{2}{l}{ Anti-carcinogenic } & \multicolumn{2}{c}{ Antioxidant } \\
\cline { 2 - 8 } & $\mathrm{Pa}$ & $\mathrm{Pi}$ & $\mathrm{Pa}$ & $\mathrm{Pi}$ & $\mathrm{Pa}$ & $\mathrm{Pi}$ & $\mathrm{Pa}$ & $\mathrm{Pi}$ \\
\hline $\mathbf{3}$ & 0.574 & 0.010 & 0.650 & 0.013 & 0.662 & 0.010 & 0.650 & 0.004 \\
$\mathbf{4}$ & 0.537 & 0.013 & 0.665 & 0.012 & 0.571 & 0.014 & 0.400 & 0.012 \\
$\mathbf{5}$ & 0.470 & 0.019 & 0.421 & 0.045 & 0.339 & 0.045 & 0.249 & 0.036 \\
$\mathbf{6}$ & 0.533 & 0.014 & 0.667 & 0.012 & 0.406 & 0.030 & 0.309 & 0.021 \\
$\mathbf{7}$ & 0.545 & 0.013 & 0.700 & 0.010 & 0.449 & 0.024 & 0.315 & 0.021 \\
$\mathbf{8}$ & 0.545 & 0.013 & 0.700 & 0.010 & 0.449 & 0.024 & 0.315 & 0.021 \\
TC & 0.694 & 0.005 & 0.523 & 0.023 & - & - & - & - \\
FCZ & - & - & 0.726 & 0.008 & - & - & - & - \\
\hline
\end{tabular}

$\mathrm{TC}=$ tetracycline; FCZ = fluconazole; $\mathrm{Pa}=$ Probability to be active; $\mathrm{Pi}=$ Probability to be inactive.

\section{ADMET and drug-likeness properties}

For the drug development, pharmacokinetics, and safety properties such as absorption, distribution, metabolism, excretion, and toxicity (ADMET) play a significant role. We have used pkCSM predictive model $(28,34)$ to rapidly evaluate pharmacokinetic and toxicity properties. As shown in Table 3, these SEs 4-8 have good absorption [Caco-2 (colon cancer cell line) permeability and human intestinal absorption (HIA)] with better permeability through BBB (blood brain barrier) and CNS (central nervous system) comparable to the standard antibiotic fluconazole. Metabolism is predicted based on the CYP model (CYP3A4) which indicated that esters 5-8 (except 4) are the CYP3A4 substrate. The in silico pkCSM also indicated that these rhamnopyranoside esters 4-8 are safer drug candidate with low toxicity as they are non-inhibitor of the human ether-a-gogo-related gene ( $h E R G)$. It should be noted that inhibition of hERG by drugs causes long QT syndrome and sudden death of patients with cardiac ischemia.

Drug-likeness (35) and medicinal chemistry friendliness of these compounds were predicted by SwissADME predictor (35) and Molsoft's chemical fingerprints (30). The results are presented in Table 4, and indicated that all the SEs (except dimesylate 5) have good topological polar surface area (TPSA, below $140 \AA^{2}$ ) which is in agreement with the most important rule of drug-likeness. Also, these SEs 4-8 did not violate pan-assay interference compounds (PAINS). PAINS are chemical compounds that often give false positive results in high-throughput screens. However, we observed that drug-likeness model scores as predicted by MolSoft were in the borderline (>-0.99) (Figure S6). 
Table 3. ADMET calculation of rhamnopyaranoside derived SEs 3-8.

\begin{tabular}{|c|c|c|c|c|c|c|c|c|c|}
\hline \multirow{3}{*}{ Drug } & \multicolumn{3}{|c|}{ Absorption } & \multicolumn{2}{|c|}{ Distribution } & \multirow{3}{*}{$\begin{array}{c}\text { Metabolism } \\
\text { CYP3A4 } \\
\text { substrate }\end{array}$} & \multirow{3}{*}{$\begin{array}{c}\text { Excretion } \\
\text { Total } \\
\text { clearance }\end{array}$} & \multicolumn{2}{|c|}{ Toxicity } \\
\hline & \multirow[t]{2}{*}{$\mathrm{C} 2 \mathrm{P}$} & \multirow{2}{*}{$\begin{array}{l}\text { HIA } \\
(\%) \\
\end{array}$} & \multirow{2}{*}{$\begin{array}{l}\text { P- } \\
\text { gpl }\end{array}$} & BBB & CNS & & & hERG & $\mathrm{LD}_{50}$ \\
\hline & & & & \multicolumn{2}{|c|}{ permeability } & & & inhibitor & \\
\hline 3 & 0.648 & 75.31 & No & -0.67 & -3.162 & No & 0.628 & No & 1.403 \\
\hline 4 & 0.635 & 72.84 & No & -0.679 & -3.041 & No & 0.350 & No & 2.562 \\
\hline 5 & 0.97 & 60.62 & No & -2.058 & -3.101 & Yes & 0.518 & No & 2.284 \\
\hline 6 & 1.161 & 93.19 & Yes & -1.188 & -2.511 & Yes & 0.021 & No & 2.411 \\
\hline 7 & 0.938 & 86.23 & No & -1.38 & -2.889 & Yes & 0.361 & No & 2.457 \\
\hline 8 & 0.938 & 81.98 & Yes & -1.417 & -2.76 & Yes & 0.423 & No & 2.192 \\
\hline FCZ & 1.191 & 87.82 & No & -1.200 & -3.221 & No & 0.386 & No & 2.210 \\
\hline
\end{tabular}

${ }^{*} \mathrm{C} 2 \mathrm{P}$ is Caco-2 permeability ( $\log$ Papp in $10^{-6} \mathrm{~cm} / \mathrm{s},>0.90$ indicates high permeability); HIA = Human intestinal absorption ( $\%$ absorbed, $>30 \%$ is better absorbed); P-gpl = P-glycoprotein inhibitor; BBB (blood brain barrier) is mentioned as $\log B B(\log B B>-1.0$ is moderately cross blood brain barrier); CNS is expressed as logPS (logPS>-2.0 can easily penetrate the CNS); Total clearance is expressed in log $\mathrm{mL} / \mathrm{min} / \mathrm{kg}$; Toxicity is calculated as hERG inhibitor, and oral rat acute toxicity $(\mathrm{mol} / \mathrm{kg}) ; \mathrm{FCZ}=$ fluconazole.

Table 4. Calculation of drug-likeness properties using SwissADME and Molinspiration.

\begin{tabular}{|c|c|c|c|c|c|c|c|c|c|c|}
\hline \multirow{2}{*}{ Drug } & \multirow{2}{*}{ HBA } & \multirow{2}{*}{ HBD } & \multirow{2}{*}{$\begin{array}{c}\text { TPSA } \\
\AA^{2}\end{array}$} & \multicolumn{5}{|c|}{ Inhibitors } & \multirow{2}{*}{$\begin{array}{l}\text { PAINS } \\
\text { alerts }\end{array}$} & \multirow{2}{*}{$\begin{array}{c}\text { Drug } \\
\text { likeness } \\
\text { score }\end{array}$} \\
\hline & & & & CYP1A2 & CYP2C19 & CYP2C9 & CYP2D6 & CYP3A4 & & \\
\hline 3 & 5 & 3 & 79.15 & No & No & No & No & No & 0 & -0.48 \\
\hline 4 & 6 & 2 & 85.22 & No & No & No & No & No & 0 & -0.19 \\
\hline 5 & 10 & 0 & 148.26 & No & No & No & No & No & 0 & -0.99 \\
\hline 6 & 8 & 0 & 97.36 & No & Yes & No & Yes & Yes & 0 & -0.64 \\
\hline 7 & 8 & 0 & 97.36 & No & Yes & Yes & Yes & Yes & 0 & -0.42 \\
\hline 8 & 8 & 0 & 97.36 & No & No & Yes & Yes & Yes & 0 & -0.51 \\
\hline
\end{tabular}

area, PAINS = Pan-assay interference compounds.

\section{CONCLUSION}

Dibutyltin oxide (DBTO) method was successfully applied for the regioselective esterification of rhamnopyranoside 3, and obtained monosubstitution single product $\mathbf{4}$, indicating regioselectivity at C-3 position. Compound $\mathbf{4}$ was further converted into four novel 2,4-di-O-acyl esters 5-8 with four non-traditional acylating agents. The high selectivity, the cleanness of the reactions, easy work-up procedures, and high yields proved the use of these reagents highly encouraging in comparison to other traditional reagents employed for selective acylation of carbohydrate derivatives. Thermodynamic properties based on DFT optimization, PASS predication and drug-likeness molecular properties of these novel rhamnopyranoside esters are also discussed. Thus, it is expected that the present study provide future prospect of rhamopyranoside-based biodegradable and ecofriendly drugs especially antimicrobial agents.

\section{ACKNOWLEDGMENT}

We are grateful to the Ministry of Education, Bangladesh and BANBEIS for financial support (grant no. PS 201660, 2016-17) to conduct this research work.

\section{REFERENCES}

1. Matin MM, Bhattacharjee SC, Chakraborty P, Alam MS. Synthesis, PASS predication, in vitro antimicrobial evaluation and pharmacokinetic study of novel $n$-octyl glucopyranoside esters.

Carbohydrate Research. 2019;485:107812. Doi:

10.1016/j.carres.2019.107812

2. Pöhnlein M, Slomka C, Kukharenko O, Gärtner T, Wiemann LO, Sieber V, Syldatk C, Hausmann R. Enzymatic synthesis of amino sugar fatty acid esters. European Journal of Lipid Science and Technology. 2014;116:423. Doi:

10.1002/ejlt.201300380

3. Matin MM, Hasan MS, Uzzaman M, Bhuiyan MMH, Kibria SM, Hossain ME, Roshid MHO. Synthesis, spectroscopic characterization, molecular docking, and ADMET studies of mannopyranoside esters as antimicrobial agents. Journal of Molecular Structure. 2020;1222:128821. Doi:

10.1016/j.molstruc.2020.128821

4. Neta NS, Teixeira JA, Rodrigues LR. Sugar ester surfactants: Enzymatic synthesis and applications in food industry. Critical Reviews in Food Science and Nutrition. 2015;55(5):595-610, Doi: 10.1080/10408398.2012.667461 
5. Lou X. Antimicrobial structure-efficacy relationship of sugar fatty acid esters. Journal of Chemical and Pharmaceutical Research. 2014;6(5):944-946.

6. Akanbi TO, Barrow CJ. Enzymatic production of antioxidants and their applications. In: Encyclopedia of Food Chemistry; Elsevier; 2019, pp 92-96. Doi: 10.1016/B978-0-08-100596-5.21646-6

7. Traxler $\mathrm{P}$, Fritz $\mathrm{H}$, Fuhrer $\mathrm{H}$, Richter WJ. Papulacandins, a new family of antibiotics with antifungal activity. Structures of papulacandins A, B, C and D. Journal of Antibiotics. 1980;33(9):967-978. Doi: 10.7164/antibiotics.33.967

8. Watanabe T, Katayama S, Matsubara M, Honda Y, Kuwahara M. Antibacterial carbohydrate monoesters suppressing cell growth of Streptococcus mutans in the presence of sucrose. Current Microbiology. 2000;41:210-213. Doi: 10.1007/s002840010121

9. Matin MM, Bhuiyan MMH, Kabir E, Sanaullah AFM, Rahman MA, Hossain ME, Uzzaman M. Synthesis, characterization, ADMET, PASS predication, and antimicrobial study of 6-O-lauroyl mannopyranosides. Journal of Molecular Structure. 2019;1195:189-197. Doi:

10.1016/j.molstruc.2019.05.102

10. Matin MM. One step intramolecular cyclization of diol via mesylation: Efficient synthesis of sugar derived $[1,4]$ oxazepanes. Journal of Bangladesh Chemical Society. 2008;21(2):179-183.

11. Dhavale DD, Matin MM. Piperidine homoazasugars: Natural occurrence, synthetic aspects and biological activity study. ARKIVOC. 2005;2005(3):110-132. Doi: 10.3998/ark.5550190.0006.314

12. Yang L-J, Yang X-D, Yang S, Zhao J-F, Zhang H-B, Liang Li. Two new benzoyl esters of glucose from Lagotis yunnanensis. Chemistry of Natural Compounds. 2006;42(6):649-651. Doi: $10.1080 / 1028602031000093366$

13. Jung ME, Koch $P$. An efficient synthesis of the protected carbohydrate moiety of brasilicardin A. Organic Letters. 2011;13(14):3710-3713. Doi: $10.1021 / 012013704$

14. Komatsu K, Tsuda M, Tanaka Y, Mikami Y, Kobayashi J. SAR studies of brasilicardin A for immunosuppressive and cytotoxic activities.

Bioorganic \& Medicinal Chemistry. 2005;13(5):15071513. Doi: 10.1016/j.bmc.2004.12.029

15. Kim SR, Kim YC. Neuroprotective phenylpropanoid esters of rhamnose isolated from roots of Scrophularia buergeriana. Phytochemistry. 2000;54(5):503-509. Doi: 10.1016/s0031-

$9422(00) 00110-2$
16. Elmaidomy AH, Mohammed R, Owis Al, Hetta $M H$, AboulMagd AM, Siddique AB, Abdelmohsen UR, Rateb ME, Sayed KAE, Hassan, HM. Triple-negative breast cancer suppressive activities, antioxidants and pharmacophore model of new acylated rhamnopyranoses from Premna odorata. RSC Advances. 2020;10:10584. Doi: $10.1039 / \mathrm{d} 0 \mathrm{ra} 01697 \mathrm{~g}$

17. Matin MM. Synthesis and antimicrobial study of some methyl 4-O-palmitoyl- $\alpha$-L-rhamnopyranoside derivatives. Orbital: The Electronic Journal of Chemistry. 2014;6(1):20-28. Doi: 10.17807/orbital.v6i1.553

18. Uddin MT, Kabir AKMS, Manchur MA. Synthesis and antimicrobial activities of some derivatives of $L$ rhamnose. Pakistan Journal of Biological Sciences. 2004;7(12):2192-2197. Doi:

$10.3923 /$ pjbs.2004.2192.2197

19. Matin MM, Chakraborty P, Alam MS, Islam MM, Hanee U. Novel mannopyranoside esters as sterol $14 \alpha$-demethylase inhibitors: Synthesis, PASS predication, molecular docking, and pharmacokinetic studies. Carbohydrate Research. 2020;496:108130. Doi:

10.1016/j.carres.2020.108130

20. Matin MM, Uzzaman M, Chowdhury SA, Bhuiyan $\mathrm{MMH}$. In vitro antimicrobial, physicochemical, pharmacokinetics, and molecular docking studies of benzoyl uridine esters against SARS-CoV-2 main protease. Journal of Biomolecular Structure and Dynamics. 2020 (in press). Doi: $10.1080 / 07391102.2020 .1850358$

21. Jäger M, Minnaard AJ. Regioselective modification of unprotected glycosides. Chemical Communications. 2016;52:656-664. Doi: $10.1039 / \mathrm{C} 5 \mathrm{CC} 08199 \mathrm{H}$

22. Ren DB, Zhang L, Zhang M. Progress on selective acylation of carbohydrate hydroxyl groups. Asian Journal of Organic Chemistry. 2019;8(10): 18131823. Doi: 10.1002/ajoc.201900400

23. Matin MM, Chakraborty P. Synthesis, spectral and DFT characterization, PASS predication, antimicrobial, and ADMET studies of some novel mannopyranoside esters. Journal of Applied Science \& Process Engineering. 2020;7(2):572-586. Doi: 10.33736/jaspe.2603.2020

24. Kiyoshima K, Sakamoto M, Ishikura T, Fukagawa Y, Yoshioka T, Naganawa H, Sawa T, Takeuchi T. Application of dibutyltin oxide method to regioselective acylation and alkylation of tylosin at C-4". Chemical and Pharmaceutical Bulletin. 1989;37(4):861-865. doi: 10.1248/cpb.37.861 
25. Kabir AKMS, Alauddin M, Matin MM, Battacharjee SC. Regioselective monobenzoylation of methyl $\alpha-L-$ rhamnopyranoside. Chittagong University Studies, Part II: Science. 1997;21(2):59-63.

26. Frisch MJ, Trucks GW, Schlegel HB, Scuseria GE Robb MA, Cheeseman JR, Scalmani G, Barone V, Petersson PA, Nakatsuji H. Gaussian 09, 2013, Gaussian Inc. (Wallingford CT).

27. Filimonov DA, Lagunin AA, Gloriozova TA, Rudik AV, Druzhilovskii DS, Pogodin PV, Poroikov VV. Prediction of the biological activity spectra of organic compounds using the PASS online web resource. Chemistry of Heterocyclic Compounds. 2014;50(3):444-457. Doi: 10.1007/s10593-0141496-1

28. Pires, DEV, Blundell TL, Ascher DB. pkCSM: predicting small-molecule pharmacokinetic properties using graph-based signatures. Journal of Medicinal Chemistry. 2015;58(9):4066-4072.

29. Daina A, Michielin O, Zoete V. SwissADME: a free web tool to evaluate pharmacokinetics, druglikeness and medicinal chemistry friendliness of small molecules, Scientific Report. 2017;7:42717.

30. Kilic-Kurt Z. Synthesis of novel oxadiazole derivatives, molecular properties prediction, and molecular docking studies. Journal of Turkish
Chemical Society, Section A: Chemistry. 2020;7(3):753-74. Doi: 10.18596/jotcsa.705951

31. Tsuda Y, Haque ME, Yoshimoto K. Regioselective monoacylation of some glycopyranosides via cyclic tin intermediates. Chemical and Pharmaceutical Bulletin. 1983;31:1612-1624. Doi: $10.1248 / \mathrm{cpb} .31 .1612$

32. Matin MM, Ibrahim M. Synthesis of 2,3-di-Osubstituted derivatives of methyl $4-O$-acetyl- $\alpha$-Lrhamnopyranoside. The Chittagong University Journal of Science. 2006;30(2):67-76.

33. Lagunin A, Stepanchikova A, Filimonov D, Poroikov V. PASS: prediction of activity spectra for biologically active substances. Bioinformatics. 2000;16(8):747-748. Doi:

10.1093/bioinformatics/16.8.747

34. Tok F, Kaymakçığlu B, ilhan R, Yılmaz S, Kırmızıbayrak $P$, Tok T. Design, synthesis, biological evaluation and molecular docking of novel molecules to PARP-1 enzyme. Turkish Journal of Chemistry. 2019;43(5):1290-1305.

35. Emen FM, Demïrdöğen RE, Avşar G, Kılıç D. 2Chlorobenzoylthiourea-modified MCM-41 for drug delivery. Journal of the Turkish Chemical Society Section A: Chemistry. 2019;6(1):29-34. 


\section{SUPPLEMENTARY DATA}

\section{Regioselective Synthesis of Some Rhamnopyranoside Esters for PASS Predication, and ADMET Studies}

Mohammed M. Matin ${ }^{1 *}$, Naimul Islam¹, Ayesha Siddika ${ }^{1}$, Sreebash C. Bhattacharjee ${ }^{1,2}$ ${ }^{1}$ University of Chittagong, Faculty of Science, Department of Chemistry, 4331, Chattogram, Bangladesh. ${ }^{2}$ Bangladesh Council of Scientific \& Industrial Research (BCSIR), Chemical Research Division, 4220, Chattogram, Bangladesh.

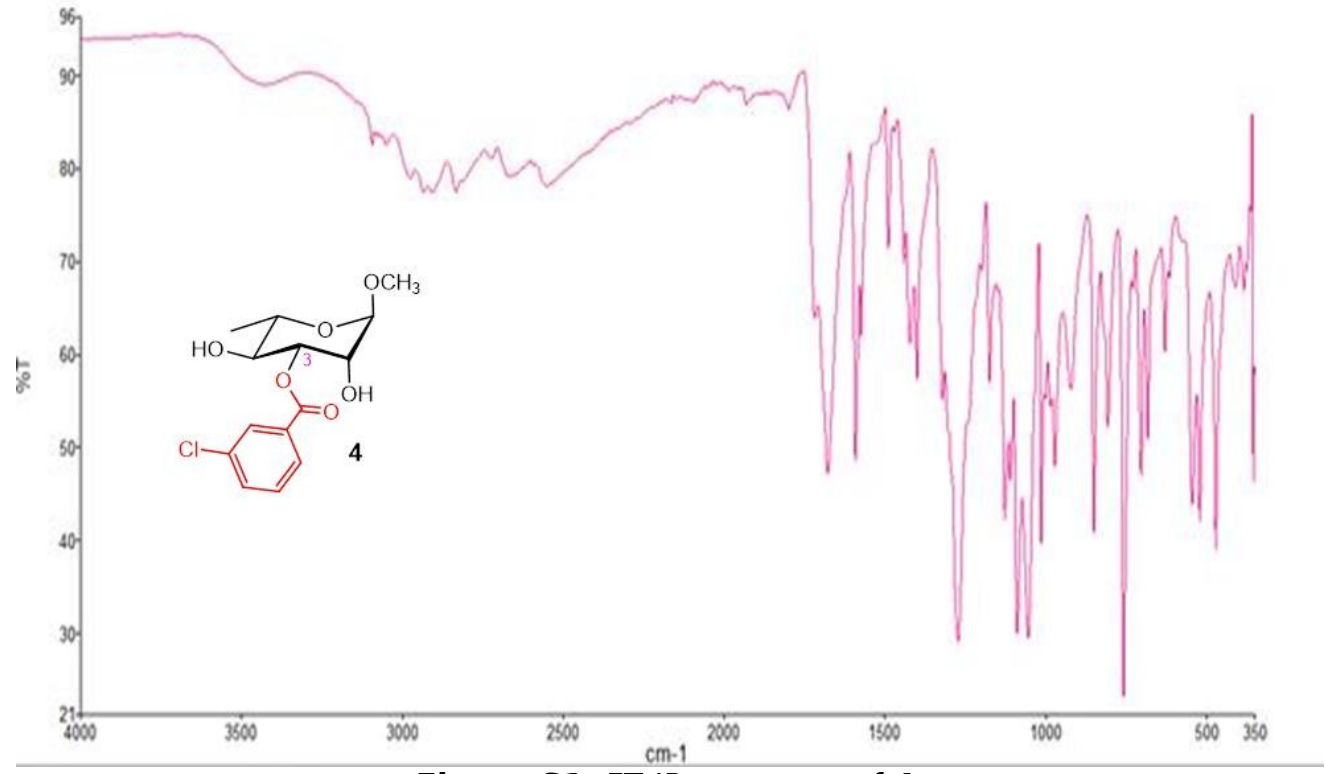

Figure S1. FT-IR spectrum of 4

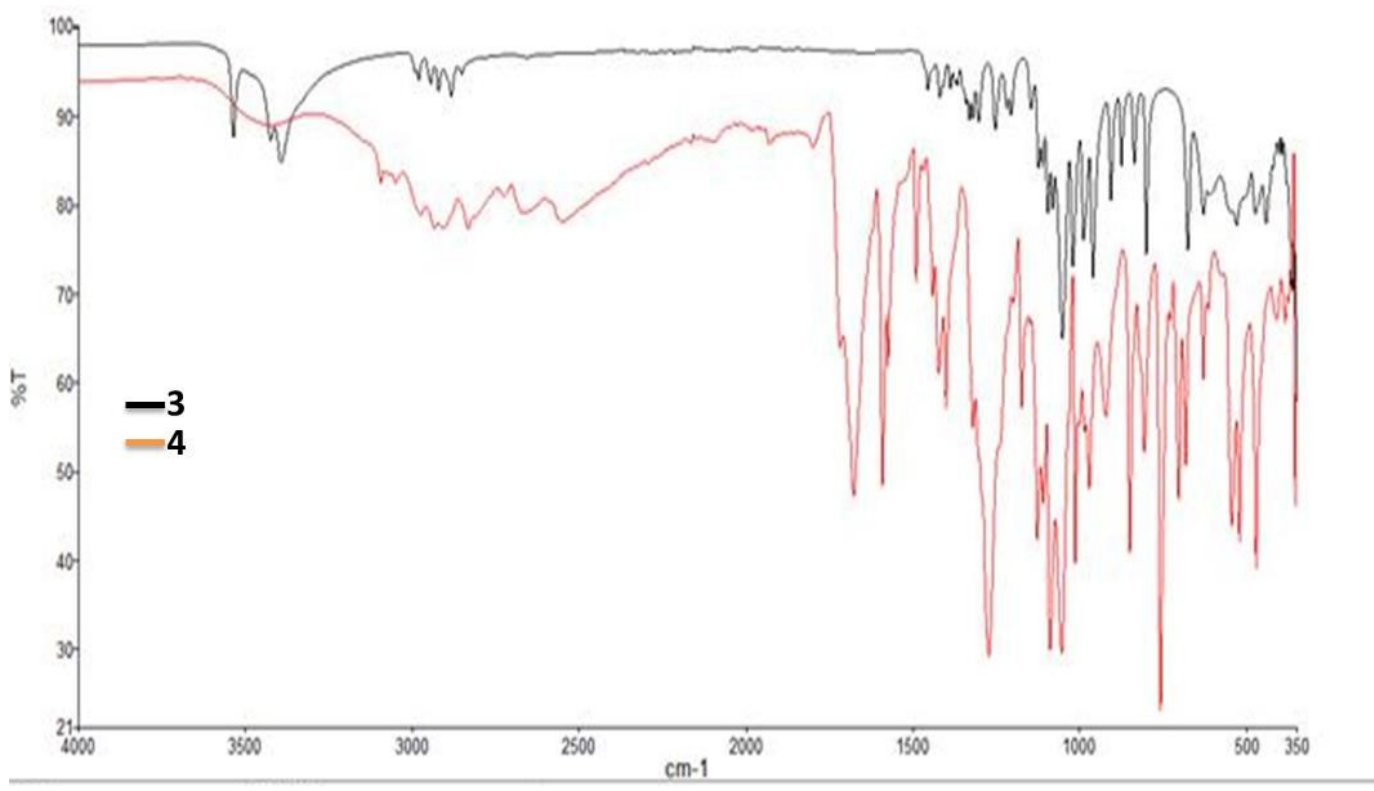

Figure S2. Comparative FT-IR spectra of compound $\mathbf{3}$ and $\mathbf{4}$. 


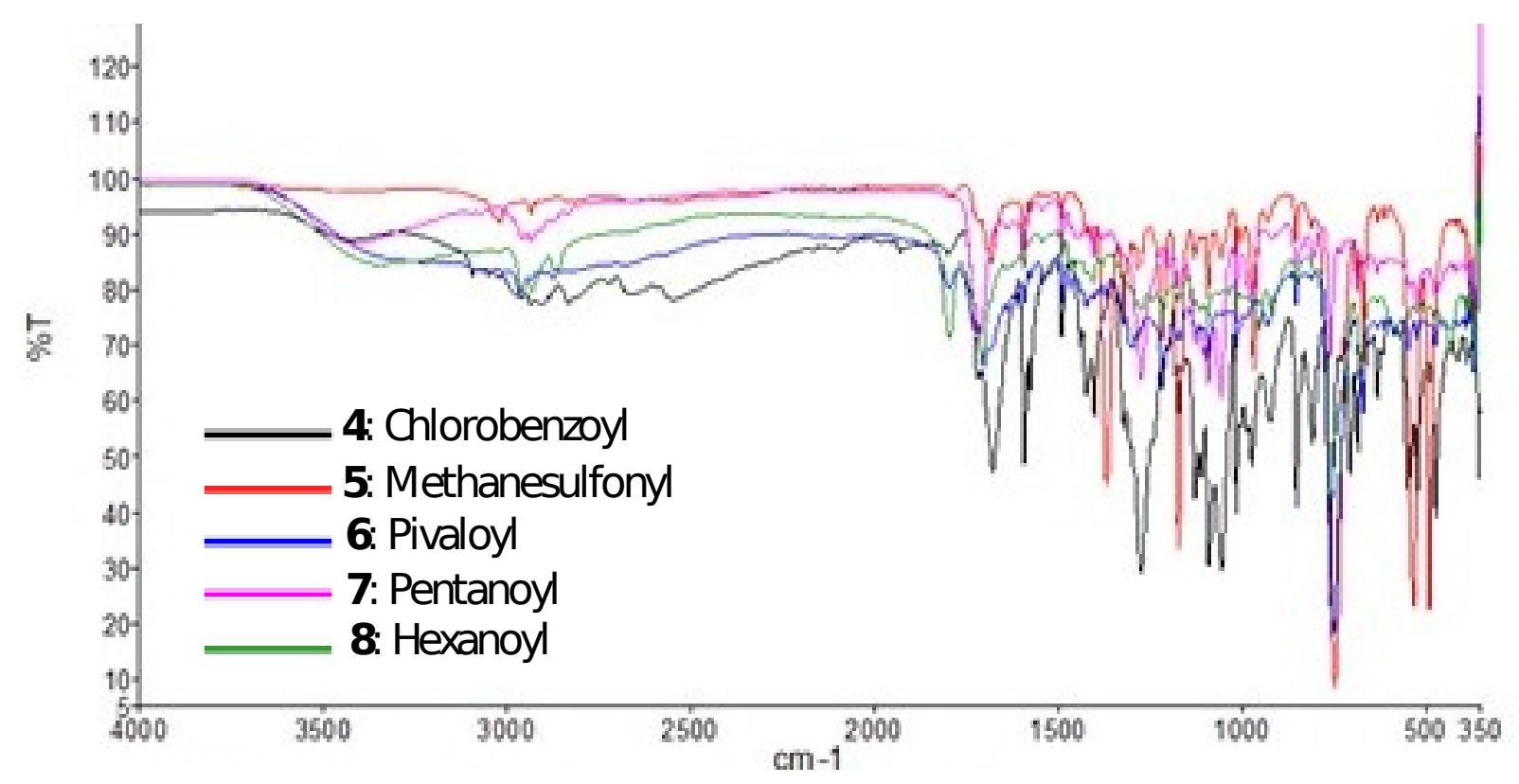

Figure S3. Comparative FT-IR spectra of compound 4-8.

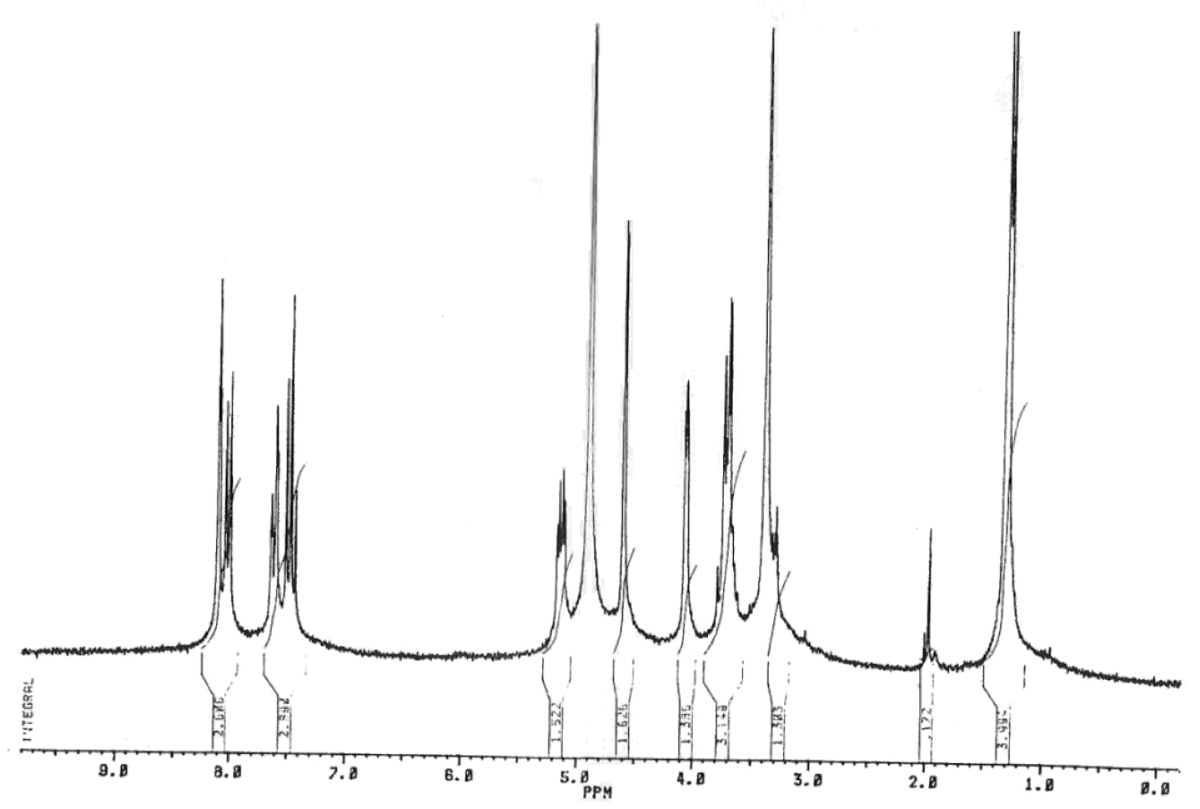

Figure S4. ${ }^{1} \mathrm{H}$ NMR $\left(400 \mathrm{MHz}, \mathrm{CDCl}_{3}\right)$ spectrum of 4. 

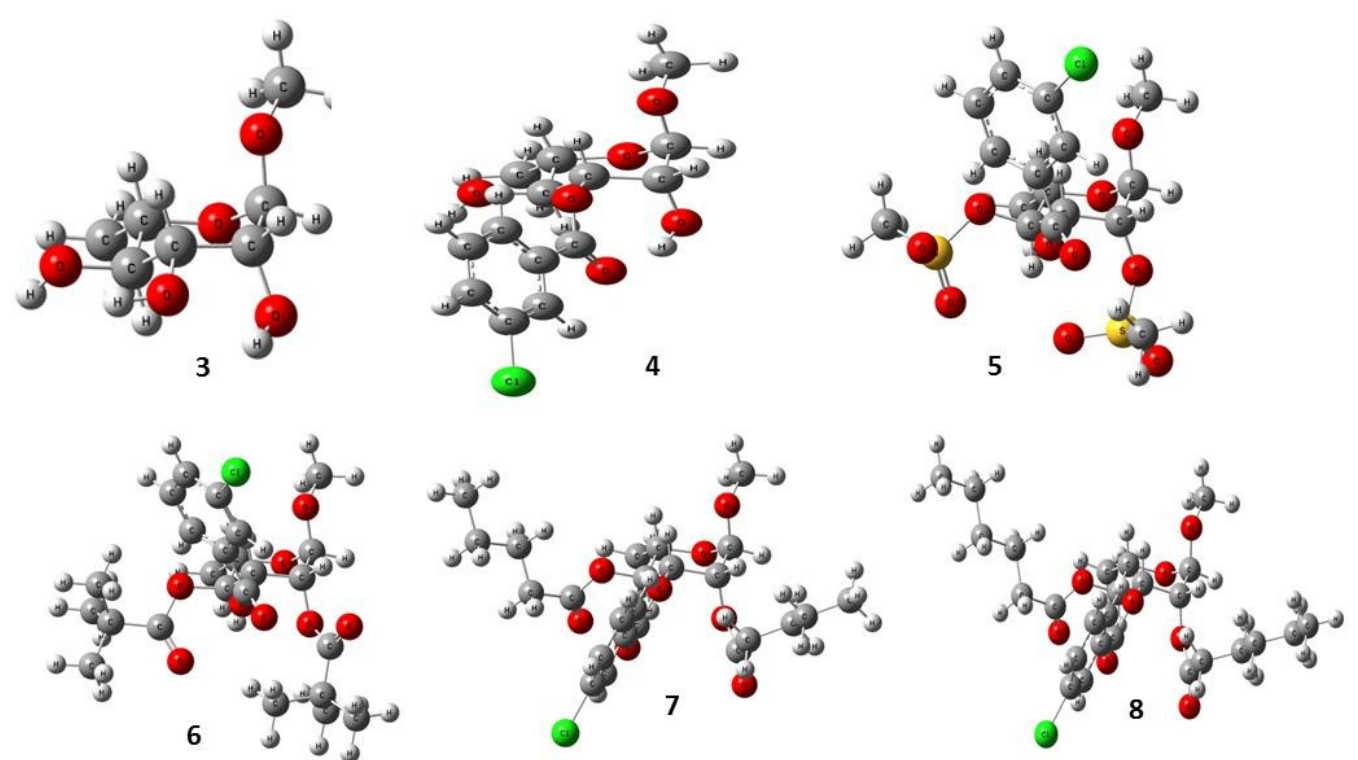

Figure S5. DFT optimized (B3LYP/3-21G) structures of rhamnopyranoside 3-8 (ball and stick model).
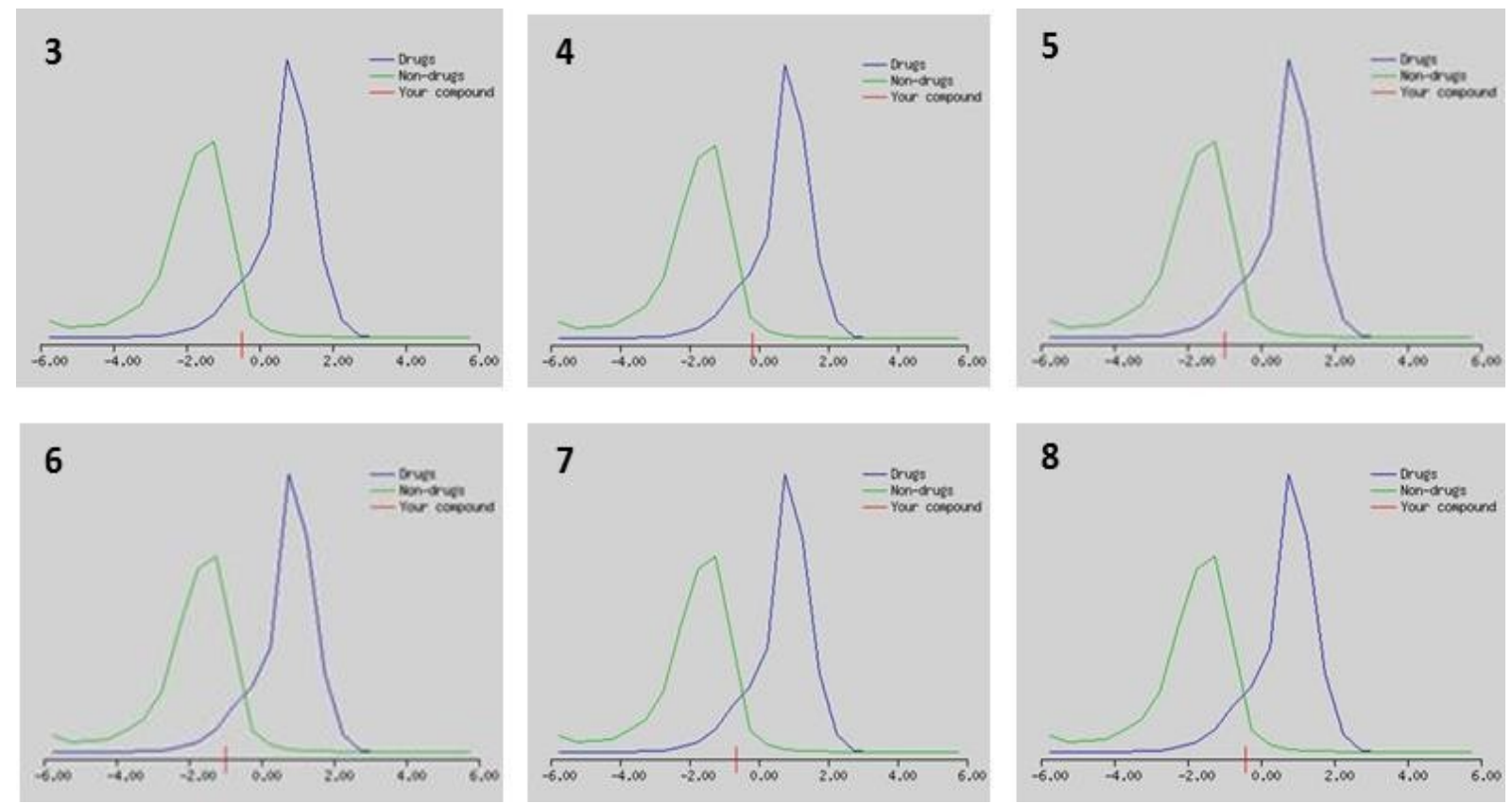

Figure S6. Druglikeness model score of SEs 4-8 predicted by MolSoft software. 